\title{
EU FP7 Project 'CAMbrella' to Build European Research Network for Complementary and Alternative Medicine
}

\author{
Wolfgang Weidenhammer ${ }^{\mathrm{a}} \quad$ George Lewith $^{\mathrm{b}}$ Torkel Falkenberg $^{\mathrm{c}}$ Vinjar Fønneb $\varnothing^{\mathrm{d}}$ \\ Helle Johannessen ${ }^{\mathrm{e}}$ Bettina Reiter ${ }^{\dagger}$ Bernhard Uehleke ${ }^{\mathrm{g}}$ Klaus von Ammon ${ }^{\mathrm{h}}$ \\ Franziska Baumhöfener ${ }^{i}$ Benno Brinkhaus ${ }^{j}$ \\ ${ }^{a}$ Competence Centre for Complementary Medicine and Naturopathy (KoKoNat), Klinikum rechts der Isar, Technische Universität, \\ Munich, Germany \\ ${ }^{b}$ Complementary and Integrated Medicine Research Unit, University of Southampton, UK \\ ${ }^{\mathrm{c}}$ Research Unit for Integrative Healthcare Research, Karolinska Institute, Stockholm, Sweden \\ ${ }^{\mathrm{d}}$ National Research Center on Complementary and Alternative Medicine (NAFKAM), University of Troms $\varnothing$, Norway \\ ${ }^{\mathrm{e}}$ Institute of Public Health, Research Unit Health, Man and Society, University of Southern Denmark, Odense, Denmark \\ ${ }^{f}$ International Academy for Holistic Medicine, Vienna, Austria \\ ${ }^{9}$ Institute of Complementary Medicine, Dept. of Internal Medicine, University Hospital Zurich, \\ ${ }^{\mathrm{h}}$ Institute of Complementary Medicine (KIKOM), University of Berne, Switzerland \\ ' Bavarian Research Alliance, Munich, \\ j Institute for Social Medicine, Epidemiology, and Health Economics, Charité - University Medical Center, Berlin, Germany
}

\section{Keywords}

Complementary medicine $\cdot$ Research roadmap · Coordination . Network · Framework programme · CAMbrella

\section{Summary}

Background: The status of complementary and alternative medicine (CAM) within the EU needs clarification. The definition and terminology of CAM is heterogeneous. The therapies, legal status, regulations and approaches used vary from country to country but there is widespread use by EU citizens. A coordination project funded by the EU has been launched to improve the knowledge about CAM in Europe. Objectives and Methods: The project aims to evaluate the conditions surrounding CAM use and provision in Europe and to develop a roadmap for European CAM research. Specific objectives are to establish an EU network involving centres of research excellence for collaborative projects, to develop consensus-based terminology to describe CAM interventions, to create a knowledge base that facilitates the understanding of patient demand for CAM and its prevalence, to review the current legal status and policies governing CAM provision, and to explore the needs and attitudes of EU citizens with respect to CAM. Based on this information a roadmap will be created that will enable sustainable and prioritised future European research in CAM. CAMbrella encompasses 16 academic research groups from 12 European countries and will run for 36 months starting from January 2010. The project will be delivered in 9 work packages coordinated by a Management Board and directed by a Scientific Steering Committee with support of an Advisory Board. Output: The outcomes generated will be disseminated through the project's website, peer review open access publications and a final conference, with emphasis on current and future EU policies, addressing different target audiences.

\section{Schlüsselwörter \\ Komplementärmedizin · Forschungsagenda - Koordinierung · Netzwerk · Forschungsrahmenprogramm · CAMbrella}

\section{Zusammenfassung}

Hintergrund: Die Situation der Komplementärmedizin (CAM) in der EU bedarf der genaueren Betrachtung. Die Definition von CAM und die verwendete Terminologie sind uneinheitlich. Rechtsstatus und Regulierung sowie die eingesetzten Therapieverfahren und Methoden variieren von Land zu Land, während CAM EU-weit häufig genutzt wird. Ein von der EU finanziertes Koordinierungsprojekt wurde gestartet, um den Kenntnisstand bezüglich der Situation von CAM in Europa zu verbessern. Ziele und Methoden: Ziel des Projektes ist die Beschreibung der Bedingungen rund um Gebrauch und Angebot von CAM in Europa sowie die Entwicklung einer Agenda für künftige europäische CAM Forschung. Weitere Ziele sind, ein EU-weites Netzwerkes von Forschungszentren für künftige Gemeinschaftsprojekte einzurichten, eine übereinstimmende Terminologie zur Beschreibung von CAM-Interventionen zu entwickeln, das Wissen um Nachfrage und Verwendung von CAM zu verbessern, die derzeitige Gesetzeslage und Regulierung von CAM darzustellen sowie die Bedürfnisse und Einstellungen der EU-Bürger bezüglich CAM zu beleuchten. Auf dieser Grundlage soll ein Plan für relevante und nachhaltige europäische CAM-Forschung entwickelt werden. CAMbrella umfasst 16 akademische Forschungsgruppen aus 12 europäischen Ländern und läuft seit Januar 2010 über einen Zeitraum von 36 Monaten. Das Projekt, das in 9 Arbeitsgruppen aufgeteilt ist, wird von einem Management-Team unter der Leitung eines wissenschaftlichen Lenkungsausschusses koordiniert und durch einen Beirat unterstützt. Output: Die erzielten Ergebnisse werden kommuniziert mittels der Homepage des Projekts, durch frei zugängliche hochrangige wissenschaftliche Publikationen und im Rahmen einer Abschlusskonferenz mit Berücksichtigung verschiedener Zielgruppen und der möglichen Auswirkungen auf derzeitige und künftige EU-Politik.

\section{KARGER}

Fax +497614520714

Information@Karger.de

www.karger.com (c) 2011 S. Karger GmbH, Freiburg

$1661-4119 / 11 / 0182-0069 \$ 38.00 / 0$

Accessible online at:

www.karger.com/fok
Dr. Dr. Wolfgang Weidenhammer

Kompetenzzentrum für Komplementärmedizin und Naturheilkunde (KoKoNat)

Klinikum rechts der Isar, TU München

Kaiserstraße 9, 80801 München, Germany

wolfgang.weidenhammer@lrz.tu-muenchen.d 


\section{Introduction and Rationale}

The status of complementary and alternative medicine (CAM) in Europe is characterized by enormous heterogeneity in all aspects. This includes the terminology used, the methods provided, the prevalence, as well as the national legal status and regulation $[1,2]$. The diversity and plurality of opinions and attitudes towards CAM, even within a relatively small academic CAM community, renders a coordinated European approach to CAM research difficult. Consequently, a comprehensive coordination action presents a thoughtful strategic response to this challenge.

Europe-based research in this field is limited because of the restricted funding available; for instance in the UK $0.0085 \%$ of medical research funds are spent on CAM research. By contrast, more than $10 \%$ of the UK population use CAM each year and approximately $50 \%$ are lifetime users [3]; in Germany, as another example, 1-year prevalence of use is reported to be around $60 \%$ [4]. European and international recommendations (World Health Assembly and Beijing Declaration) with respect to CAM support the urgent need for further strategic research to enable appropriate decision making (EP A60379/2006, Decision No. 1350/2007/EC; WHO Fact Sheet No. 134, 2008). Outside of Europe, the National Center for Complementary and Alternative Medicine (NCCAM) is considered the leading institution providing an annual budget of approximately \$120 million for CAM research.

Previous CAM projects funded by European authorities include 'COST B4', a project on unconventional medicine in Europe set up by the European Commission (1993-1998). It rendered findings on socio-cultural aspects, research methodology and dialogue between unconventional and orthodox medicine, and made recommendations for future work in this field [5]. However, the complex and ambitious recommendations were not implemented in EU or national research strategy, restricting the long-term impact of COST B4 to providing a clear strategic concept. The project 'Concerted Action for Complementary and Alternative Medicine Assessment in the Cancer Field' (CAM-Cancer, Project No. QLG4-CT-200200786) was launched under FP5 (2002-2005). It aimed at providing information and building an international network around CAM in cancer. It is now hosted by one of the participants of CAMbrella (NAFKAM) to ensure sustainable benefit.

Unlike these projects, CAMbrella is the first EU framework programme coordination action that is explicitly related to CAM in general and not focused on a specific condition. Besides this, the view currently taken in European health policy is also pointed out in Decision No. 1350/2007/EC which stipulates that the Second Programme of Community Action in the Field of Health 'should recognise the importance of a holistic approach to public health' and that CAM should be taken into account in its actions 'where appropriate and where there is scientific or clinical evidence' [6].
In public health, the prevalence of use of CAM interventions is a key issue. The utilisation of specific methods such as acupuncture, homeopathy, herbal medicine, massage, reflexology and Reiki healing has increased exponentially in Western industrialized nations over the last 25 years [4, 7-9]. The World Health Organisation (WHO) Centre for Health Development published a global atlas of traditional, complementary and alternative medicine comprising a text and a map volume [10]. The WHO concluded that CAM is highly prevalent in the European region but was unable to draw a clear picture of CAM use across the whole EU as the evidence available was drawn from just a few member states. There is an urgent need to gather more information to gain an overview of the issues surrounding CAM, its availability and its safe and legitimate provision to EU citizens. There are currently no reliable comparisons between EU member states because they use different definitions with respect to CAM and the associated treatment methods [11]. EU-wide consensus in this field is essential to develop an understanding of EU citizens' behaviour with respect to CAM and to establish appropriate health policies in this area.

\section{Objectives}

In accordance with the call for proposals published on September 3, 2008 by the EC for the FP7-Health-2009 work programme [12], CAMbrella is designed to fulfil the following specific objectives:

- To develop consensus on a series of definitions for the terminology used to describe the major CAM interventions used clinically in Europe.

- To create a knowledge base that allows us to accurately evaluate the patient demands for CAM and the prevalence of its use in Europe.

- To review the current legal status of CAM in EU member or associated states.

- To explore the needs and attitudes of EU citizens with respect to CAM.

- To explore the providers' perspectives on CAM treatment in Europe.

- To propose an appropriate research strategy for CAM that will help develop an understanding of CAM use and its effectiveness within an EU context in response to the needs of healthcare funders, providers and patients. This will take account of the issues of effectiveness, cost, safety and the legal requirements for the production of medicinal substances.

- To develop a process for prioritizing future EU research strategy, the current policies within the EU have to be considered.

- To facilitate and foster sustainable, high quality collaboration and networking of European CAM researchers. 
Table 1. List of cooperation partners forming the CAMbrella consortium

\begin{tabular}{|c|c|c|c|}
\hline & Beneficiary name - short name & Country & Staff involved \\
\hline 1 & $\begin{array}{l}\text { Technische Universität München - Klinikum rechts der Isar (Coordinator) - } \\
\text { MRI }^{\mathrm{a}}\end{array}$ & Germany & W Weidenhammer ${ }^{\mathrm{MB}, \mathrm{SSC}}, \mathrm{M}$ Schagerl \\
\hline 2 & Wiener Internationale Akademie für Ganzheitsmedizin - GAMED & Austria & B Reiter ${ }^{\text {SSC }}$, S. Zopf \\
\hline 3 & Universitetet i Troms $\emptyset$ - NAFKAM ${ }^{\mathrm{a}}$ & Norway & $\begin{array}{l}\text { V Fønneb } \emptyset^{\text {sSC }}, \text { S Wiesener, } \\
\text { L Salomonsen }\end{array}$ \\
\hline 4 & Universität Bern - UNIBE ${ }^{a}$ & Switzerland & $\mathrm{K}$ von $\mathrm{Ammon}^{\mathrm{SSC}}$, M Frei-Erb \\
\hline 5 & University of Southampton - US & UK & G Lewith ${ }^{\text {SSC }}$, F Bishop, S Eardley, M Jong \\
\hline 6 & Charité - Universitätsmedizin Berlin - Charitéa & Germany & $\begin{array}{l}\text { B Brinkhaus }{ }^{\mathrm{MB}, \mathrm{SSC}}, \mathrm{D} \text { McBride, F Junne, } \\
\text { F. Fischer }\end{array}$ \\
\hline 7 & Universität Zürich - UZH ${ }^{\mathrm{a}}$ & Switzerland & B Uehleke ${ }^{\text {ssc }}$, J Melzer, H-W Hoefert \\
\hline 8 & $\begin{array}{l}\text { Comitato Permanente di Consenso e Coordinamento per le Medicine } \\
\text { Non-Convenzionali in Italia - ComCAM }\end{array}$ & Italy & P Roberti di Sarsina, I Iseppato \\
\hline 9 & Karolinska Institutet $-\mathrm{KI}^{\mathrm{a}}$ & Sweden & T Falkenberg ${ }^{\text {SSC }}$, J Hoek \\
\hline 10 & Université Paris $13-\mathrm{SMBH}^{\mathrm{a}}$ & France & G Delahaye, P Escure, A. Lazarus \\
\hline 11 & Servicio Andaluz de Salud - SAS & Spain & J Vas, K Santos Rey \\
\hline 12 & Agenzia sanitaria e sociale regionale - Regione Emilia-Romagna - ASSR & Italy & F Cardini, S Florindi \\
\hline 13 & Pécsi Tudományegyetem - University of Pecs - PTE ${ }^{\mathrm{a}}$ & Hungary & G Hegyi \\
\hline 14 & Universitatea de Medicina si Farmacie Victor Babes Timisoara - UMFT ${ }^{\mathrm{a}}$ & Romania & S Dragan, S. Ursoniu \\
\hline 15 & Syddansk Universitet - SDU ${ }^{\mathrm{a}}$ & Denmark & $\begin{array}{l}\text { H Johannessen }{ }^{\text {SSC }}, \text { N Nissen, J Sørensen, } \\
\text { J Madsen }\end{array}$ \\
\hline${ }^{\mathrm{a}} \mathrm{Af}$ & $\begin{array}{l}\text { iated to university. } \\
\text { mber of Management Board. } \\
\text { ember of Scientific Steering Committee. }\end{array}$ & & \\
\hline
\end{tabular}

\section{Consortium}

To achieve the project's goals, a consortium was established which encompasses 16 partners predominantly affiliated to universities from 12 European countries with nearly 40 scientists and experts in research and clinical practice directly involved (table 1). CAMbrella is coordinated and monitored by a management board and directed by a scientific steering committee with support of an advisory board and involves all the major stakeholders in CAM research in Europe. In addition to the authors of this article, the consortium includes Francesco Cardini (Italy), Gérard Delahaye (France), Simona Dragan (Romania), Gabriella Hegyi (Hungary), Paolo Roberti di Sarsina (Italy) and Jorge Vas (Spain). The current composition of the consortium is the result of a dynamic process initiated by an ad-hoc working group in December 2006. Further participants have been included during the preparatory phase of the project. Inclusion criteria were the participants' qualification with respect to the overall objective of the project and a preferably broad geographical representation of
EU member states (fig. 1). Further criteria were previous experience in international cooperation and a neutral position with respect to individual treatment methods or the interests of manufacturers of natural health products. The project is assisted by an advisory board in order to obtain input from the diverse CAM stakeholder groups including consumers, practitioners, clinical providers, and manufacturers of CAM medicinal products (table 2). Most of the institutions that have joined the board are umbrella organizations which operate at European level and thus represent a significant number of members. The board members provide advice on healthcare and technical and political issues, thereby complementing the scientific perspective of the consortium.

\section{Work Plan}

The project's work plan is divided into a total of 9 work packages (WPs), comprising content-related WPs (WP1-WP7), one for disseminating the project results (WP8) and one dedi- 


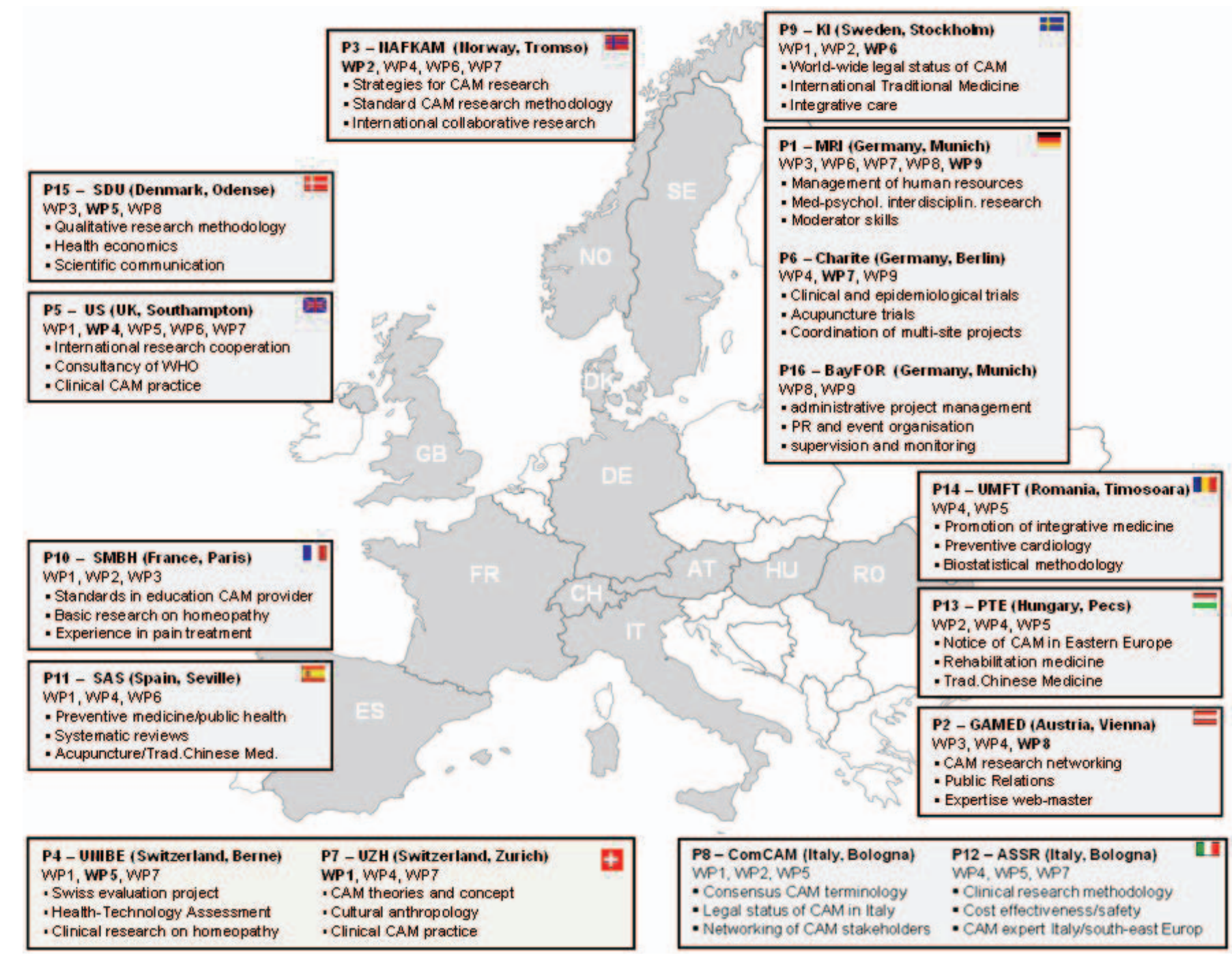

Fig. 1. Regional distribution and major expertise of the CAMbrella project partners.

Table 2. List of members of the Advisory Board

\begin{tabular}{lll}
\hline Organization & Abbreviation & Website \\
\hline Association of Natural Medicine in Europe & ANME & www.anme.info \\
European Central Council of Homeopaths & ECCH & www.homeopathy-ecch.org \\
European Coalition on Homeopathic and Anthroposophic Medicinal Products & ECHAMP & www.echamp.org \\
European Committee for Homeopathy & ECH & www.homeopathyeurope.org \\
European council of doctors for plurality in medicine & ECPM & www.ecpm.org \\
European Forum for Complementary and Alternative Medicine & EFCAM & www.efcam.eu \\
European Herbal and Traditional Medicine Practitioners' Association & EHTPA & www.ehpa.eu \\
European Information Centre for Complementary and Alternative Medicine & EICCAM & www.eiccam.eu \\
European Public Health Association & EPHA & www.epha.org \\
International Council of Medical Acupuncture and Related Techniques & ICMART & www.icmart.org \\
International Federation of Anthroposophic Medical Associations & IVAA & www.ivaa.eu \\
Kneipp-Bund eV & KB & www.kneippbund.de \\
\hline
\end{tabular}

cated to the project management (WP9). WPs 1 through 6 consider the current status of CAM in Europe and review the literature with respect to the major aspects of CAM such as terminology, methods, prevalence of use, needs and demands of citizens and providers as well as the legal status and regulation. Their findings and results constitute the basis for the concluding WP7 which will develop a roadmap for future European CAM research as one of the central outcomes of 
the CAMbrella project. For a detailed list of the objectives of all WPs see table 3 . The content-related WPs have clear interdependencies and proceed in a timely interlaced manner. The majority of the WPs will deliver their outputs in the form of written reports which will be published in peer-reviewed journals and will be accessible to the public.

One of the major tasks of the CAMbrella coordination action is to establish a reliable European network extending beyond the project consortium. The main centres of excellence in the field have been invited to cooperate. Face-to-face meetings between the partners will facilitate the exchange of ideas and thus enhance sustainable relations among the consortium members. Communication as well as the administrative project management is supported by the software tool Projectplace ${ }^{\mathrm{TM}}$ providing access for all project members. We will also draw on the experience from international activities in the field of CAM and include international organizations in our dissemination activities in order to generate relevant feedback. The stakeholders included are recognized as representatives of specific regions (such as Asia, North America, South and Latin America and the Western Pacific Region), national organizations (e.g. NIH/NCCAM, the State Administration of Traditional Chinese Medicine of the People's Republic of China and nationally appointed CAM Research and Development (R and D) centres), relevant non-governmental organisations (e.g. Cochrane Collaboration, the Osher Centers for Integrative Medicine, the Samueli Institute, and leading world federations of CAM therapies) and authoritative multilateral organizations (such as WHO/HTP/TRM, UNICEF and the World Bank).

Table 3. Brief description of the objectives of CAMbrella Work Packages 1-9, (L) indicates the Work Package leader position

WP1: Terminology and definitions of CAM methods

Work group members: $U Z H(L), U S, C O m C A M, K I, S M B H, S A S$

- Identifying and analyzing the existing terms and definitions of CAM used in scientific publications.

- Providing a core set of CAM disciplines and methods being used consistently all over Europe and an additional list of country-specific CAM disciplines and methods.

- Developing a proposal for a practical pan-European definition of CAM, its disciplines and respective methods.

WP2: Legal status and regulations

Work group members: NAFKAM (L), ComCAM, KI, SMBH, PTE

Report on the current status with respect to:

- legal status of CAM

- regulatory status and governmental supervision of CAM practices

reimbursement status of CAM practices and medicinal products

regulation of CAM medicinal products

status of EU-wide regulation of CAM practices and medicinal products

potential obstacles for EU-wide regulation of CAM practices and medicinal products.

WP3: Needs and attitudes of citizens

Work group members: SDU (L), GAMED, MRI, SMBH

- To identify cross-European indicators for population-based needs and attitudes regarding CAM.

- To identify and map the needs of European citizens with respect to CAM.

- To identify and map EU citizens' attitudes towards CAM.

- To provide information on citizens' needs and attitudes regarding CAM.

WP4: CAM use - the patients' perspective

Work group members: US (L), GAMED, NAFKAM, Charite, UZH, SAS, ASSR, PTE, UMFT

- Identify a standardised questionnaire for CAM use.

- Address the prevalence of CAM use in Europe.

- Identify the major conditions treated with CAM.

- Explore the reasons why patients choose CAM.

WP5: CAM use - the providers' perspective

Work group members: UNIBE (L), US, ComCAM, ASSR, PTE, UMFT, SDU

To identify the different models of CAM provided in European public health systems

- by registered physicians and CAM practitioners

- by country

in relation to other international perspectives. 
Table 3. Continued

WP6: CAM use - the global perspective

Work group members: $K I(L), M R I, N A F K A M, U S, S A S$

- To incorporate experiences from countries in which CAM R and D is integrated and publicly supported (US/Canada), while exploring its use as Traditional Medicine in developing countries.

- To understand the pros and cons of CAM R and D internationally addressing issues of patient rights and needs, cost, regulation, evidence base and research policy/strategy.

- To investigate risks of over-harvesting medicinal plants, and protection of traditional inherited knowledge of traditional medicine used within CAM.

To identify the R and D strategies to be addressed from an EU perspective.

WP7: Roadmap for future CAM research

Work group members: Charite (L), MRI, NAFKAM, UNIBE, US, UZH, ASSR, SDU

- Analysis of the research methods already used to identify prevalence and use of CAM in the EU.

- Develop research methods and strategies for CAM that take into account the needs and attitudes of EU citizens and providers (funders and clinicians).

- Develop research strategies and a roadmap to enable future CAM research regarding effectiveness, efficacy, cost effectiveness and safety.

WP8: Dissemination and communication

Work group members: GAMED (L), MRI, SDU, BayFOR

- To foster project internal communication and external communication with CAM stakeholders including patient and public healthcare organizations.

- To establish, host and maintain a website as the common platform for CAMbrella (www.cambrella.eu).

- To identify CAM stakeholders and appropriate target audiences in Europe through which to disseminate information generated by the project.

To plan and organize the final CAMbrella conference.

\section{WP9: Management}

Work group members: $M R I(L)$, Charite, BayFOR

- To ensure smooth and efficient project implementation and achievement of all project objectives.

- To provide daily coordination and management for the entire project.

- To provide administrative support to all participants.

- To ensure financial regularity and ethics compliance.

- To identify obstacles to running and managing the project (risk management).

- To ensure sustainability of the established network.

To report to the European Commission.

\section{Timeline}

The Grant Agreement with the EC, which includes the final Description of Work, was duly signed on October 22, 2009 and stipulates the project's duration from January 1, 2010 to December 31, 2012. The timeline for the WPs shows that most work groups will finish their tasks by the end of 2011, allowing for the development of the research roadmap. The key events are the kick-off meeting which was held in Munich on January 21-22, 2010, and the final conference which is planned for November 2012 in Brussels.

\section{Dissemination}

The central platform for the dissemination of the information generated by CAMbrella is the project website (www.cambrella.eu) which is established, hosted and maintained by WP 8. It offers information on the current status of the project, its progress and the work plan for upcoming project milestones. The website will also be used as an instrument for disseminating reports and WP activities. The website will encourage and stimulate dialogue between the project consortium and interested parties, including the publication of a regular newsletter that combines information on the project with information on relevant CAM research results.

\section{Comments}

The CAMbrella project is a work in progress and will identify CAM stakeholders and appropriate target audiences in Europe through which to disseminate information generated by the project. The impact achieved by its developments and outcomes is multi-faceted:

i) The scientific perspective: The project's WPs are designed to enhance the knowledge of CAM in the EU by developing consensus on terminology and collecting information 
about CAM use, demand for CAM and the legal regulations on CAM provision. Further objectives are to identify major conditions treated with CAM and to explore the reasons why patients choose CAM. Based on the available information, a reasonable roadmap for future research projects will be suggested to fill the existing knowledge gaps and to facilitate that CAM practice is based on appropriate evidence. All actions intend to inform EU policies and decision makers in order to identify and support research programs of excellence and ensure a solid evidence base for the delivery of all aspects of healthcare to European citizens.

ii) The coordination perspective: The project will create a coordinated EU network of researchers and stakeholders within the EU and beyond its borders. This network will also foster dialogue with patients, research and healthcare funders (both public and private) and specific provider groups such as homeopaths and acupuncturists. Various organisations, including those representing conventional medicine or patients' interests in general, are being encouraged to participate in the project. The information generated by the university-based, research-focused core of the collaboration will thus have a substantial and strong impact on how CAM is looked at and provided in the EU's diverse healthcare systems.

With respect to the limited project time it is particularly important to look for sustainable network structures. A recently established European chapter within the International Society for CAM Research (ISCMR, www.iscmr.org) provides an infrastructure which can facilitate future use of the network developed by CAMbrella. Such cooperation is also aimed at paving the way for further research projects funded by the EU's framework programmes (FP 7, as well as FP 8 starting in 2014), while simultaneously providing a pool of linked research centres for collaborative projects.

The roadmap for future European CAM research will be based on our understanding of which research activities are most prevalent and relevant for EU citizens and thus eligible for future funding by the EC. It has been suggested that the strategy in CAM research should be developed in an order that differs from that commonly used for conventional medicine [13]. Such a strategy does not contain new methodological concepts, but organises existing ideas in a way that is tailored to pragmatic clinical practice. It is a framework to guide CAM research, illustrating the necessary building blocks required for a sound evidence base. Within this 5-phase research framework, pragmatic trials are proposed as a valuable complement to placebo-controlled studies as they focus on routine clinical settings and practice [14]. Intervention approaches such as psychotherapy and other more complex interventions including CAM may be slightly modified in these contexts [15]. All of these methodological issues will be considered in our proposed strategic approach. The outcome of the CAM-focused CAMbrella project is designed to contribute to the process of developing an appropriate strategy for better healthcare in Europe. This will be soundly evidence-based and is likely to involve a wide range of different interventions.

\section{Acknowledgements}

We would like to thank all colleagues from all over the world, who gave assistance and advice to make the project possible, or support and contribute to the project. In addition to the cooperation partners listed in table 1, our thanks are also due to Anna Frejd and Virginia Nieto, and in particular to Dieter Melchart for providing generous support and resources. The CAMbrella project receives funding from the EC's 7th Framework Programme (FP7/2007-2013) under Grant Agreement No. 241951. All institutions to which the authors are affiliated receive financial support from the EU FP7 funded project budget according to their tasks and work load.

\section{Disclosure Statement}

The authors declare no conflict of interest.

\section{References}

1 Ersdal G: How are European patients safeguarded when using complementary and alternative medicine (CAM)? Jurisdiction, supervision and reimbursement status in the EEA area (EU and EFTA) and Switzerland, CAM-Cancer Project, 28 October 2005; www2.uit.no/ikbViewer/Content/163942/EEAlegal2005.pdf.

2 Dixon A, Riesberg A, Weinbrenner S, et al.: Complementary and alternative medicine in the UK and Germany. Research and evidence on supply and demand. Anglo-German Foundation for the Study of Industrial Society, 2003; www.agf.org.uk/ cms/upload/pdfs/R/2003_R1413_e_complementary_ and_alternative_medicine.pdf.

3 UK Clinical Research Collaboration: UK health research analysis. London, UK Clinical Research Collaboration, 2006. www.ukcrc.org/PDF/ UKCRC_Health_Research_Analysis_Report.pdf.
4 Härtel U, Volger E: Inanspruchnahme und Akzeptanz klassischer Naturheilverfahren und alternativer Heilmethoden in Deutschland - Ergebnisse einer repräsentativen Bevölkerungsstudie. Forsch Komplementärmed Klass Naturheilkd 2004;11: 327-334.

5 Monckton J, Belicza B, Betz W, Engelbart H, van Wassenhoven M (eds): COST Action B4: Unconventional Medicine. Final Report of the Management Committee. European Communities, Brussels, 1999.

6 Decision No. 1350/2007/EC of the European Parliament and of the Council of 23 October 2007 establishing a second programme of Community action in the field of health (2008-13); http://eurlex.europa.eu/LexUriServ/LexUriServ.do? uri=OJ:L: 2007:301:0003:0013:en:pdf.
7 Eisenberg DM, Davis RB, Ettner SL, Appel S, Wilkey S, van Rompay M, Kessler RC: Trends in alternative medicine use in the United States, 1990-1997 - results of a follow-up national survey. JAMA 1998;280:1569-1575.

8 Ernst E: Prevalence of use of complementary/al ternative medicine: a systematic review. Bulletin of the World Health Organization 2000;78:252-257.

$\checkmark 9$ Molassiotis A, Fernadez-Ortega P, Pud D, Ozden G, Scott JA, Panteli V, et al.: Use of complementary and alternative medicine in cancer patients: a European survey. Ann Oncol 2005;16:655-663.

10 Bodeker G, Ong CK, Grundy C, Burford C, Shein K: WHO Global Atlas of Traditional, Complementary and Alternative Medicine. WHO, Kobe, 2005. 
11 Hunt KJ, Coelho HF, Wider B, Perry R, Hung SK Terry P, Ernst E: Complementary and alternative medicine use in England: results from a national survey. Int J Clin Pract 2010;64:1496-1502.

12 European Commission, 2008: Work Programme 2009, Cooperation, Theme 1 Health. ftp://ftp.cordis. europa.eu/pub/fp7/docs/wp/cooperation/health/ a_wp_200901_en.pdf.
Fønneb $\varnothing$ V, Grimsgaard S, Walach H, Ritenbaugh C, Norheim AJ, MacPherson H, Lewith G, Launs $\varnothing$ L, Koithan M, Falkenberg T, Boon H, Aickin M: Researching complementary and alternative treatments - the gatekeepers are not at home. BMC Med Res Methodol 2007;7:7.
14 Cardini F, Wade C, Regalia AL, Gui S, Li W, Raschetti R, Kronenberg F: Clinical research in traditional medicine: priorities and methods. Complement Ther Med 2006;14:282-287.

15 Walach H, Falkenberg T, Fønnebø V, Lewith G, Jonas WB: Circular instead of hierarchical: methodological principles for the evaluation of complex interventions. BMC Med Res Methodol 2006;6:29. 